\title{
The Impact of Employee Empowerment on the Organizational Commitment
}

\author{
Dr. Wael Zaraket \\ Chairperson of Management Department, American University of Science and \\ Technology, USA
}

Dr. Robert Garios

Dean of the Faculty of Business and Economics, American University of Science and

Technology, USA

Ms. Layla Abdel Malek

Faculty of Business and Economics, American University of Science and Technology, USA

Received: July 30, 2018 Accepted: August 15, 2018 Online published: August 15, 2018 doi:10.5296/ijhrs.v8i3.13528 URL: https://doi.org/10.5296/ijhrs.v8i3.13528

\begin{abstract}
Organizational commitment has been a topic of extensive interest since 1950 due to its substantial implications on both employees and organizations. Therefore, it is crucial for every company to determine and understand the aspects which boost the commitment of its employees thus leading to achieve its objectives and optimize the human capital. Hence, the purpose of this research was to analyze the impact of core components of employee empowerment on the organizational commitment in the Lebanese Banking sector.

This research adopted the principles of positivism where the researcher was independent from the study. Since the study was already grounded from an existing theoretical framework with the purpose of testing hypotheses, the deductive approach was followed. After studying the existing literature related to the subject, the researcher conducted a quantitative study. The data was distributed and collected from 123 employees working in the Lebanese Banking sector using a self-administered questionnaire. The aim of this questionnaire was to explore the influence of job autonomy, motivation, training and compensation on organizational commitment.
\end{abstract}

The hypotheses which were proposed to be tested during the research were verified. The 
results reflected a positive relation between the components of employee empowerment and organizational commitment. This was in alignment with the other business sectors in Lebanon and in similar banking sector in the region and the West. Accordingly, the banks should consider employee empowerment as one of the factors in promoting organizational commitment. Consequently, this leads to employees' organizational retention in the Lebanese Banking sector.

Keywords: employee empowerment, job autonomy, motivation, training, compensation, organizational commitment, Lebanon, banking sector

\section{Introduction}

Nowadays, organizations are focusing on gaining a competitive advantage in the marketplace after the paradigm of globalization era has fetched hasty deviations and modifications, for both technological and environmental industries. Advanced machines and equipment, new technologies, effective marketing strategies, unique customer services, and other components represent the factors that build up for this advantage. Thus, organizations are always advancing their systems, processes, and technologies to cope with the challenging existing environment. In addition, the dynamic contemporary environment is urging its organizations to synchronize their management techniques with these increasing problems.

For a company to survive and achieve its concerned goals and missions in today's competitive world, one of the most important tools is the human element. It is the most crucial asset of an enterprise whose success or failure depends on the individuals' qualifications and performance. Technologies, processes, and products are easily copied; however, individuals will stay the most strategic resource for the company. They stay the repository of knowledge which competitors can't imitate.

Hence, a new management technique enrolled to face the arising challenges is employee empowerment or participative management that involves the individuals responsible for the work. Empowerment role is to improve the performance of the employees in the organization by making them more competent in their workplace. Empowering the human resources maximizes the resource itself and generates organizational commitment among them which is perceived as a way of differentiating one organization from another. Moreover, empowered workers feel more confident and self-reliant to influence their work environment by being more proactive and innovative. Allowing individuals to have both independence and feedback within their company makes the empowerment process successful.

However, employee empowerment doesn't mean that managers isolate themselves from their responsibilities but rather their responsibility comes to create and foster an environment in which the employee's input is anticipated and cultivated. However, high levels of confidence might be taken too far ending up in crossing the line towards arrogance which makes it difficult to deal with such employees and take directions well. Operating in this kind of work environment takes its toll on employees and they once again become dissatisfied resulting in the decrease in their productivity levels. 


\subsection{Statement of the Problem}

The Lebanese banking sector is facing problems with the underperformance and lack of commitment of its employees. Thus, managers are trying to find the reasons behind this situation even though they have good human resource (HR) practices. The low level of organizational commitment is characterized by the lack of accepting the organizational goals and not exerting effort to remain with the organization (Reichers, 1985). The employee who operates on this level must be disillusioned about the organization; such an employee may stay because he or she needs to stay as associated with the continuance dimension (Meyer \& Allen, 1997) given an option he/she will leave the organization. By knowing what drives the commitment of employees, a positive environment can be created to deliver tangible results quickly.

Moreover, Employee empowerment is often a misunderstood concept in the workplace that few managers put into practice because they believe that this process will reduce their authority. In addition, researchers have discovered through studies that many managers don't really recognize the significance of employee empowerment and its effect on the organizational commitment (Emerson, 2012).

\subsection{Objective of the Study}

The aim of this study is to discover the relationship between core dimensions of employee empowerment and organizational commitment in the Lebanese banking sector where there was always a research scarcity in studying these variables not only in Lebanon but in the globe. There are many reasons for choosing this industry in particular. First, the Lebanese banking sector is the most prominent sector in Lebanon making it highly competitive. It is also facing a rapidly changing environment (Achi \& Ayache, 2001). These facts render this industry as an abundant ground for researchers to be studied. Moreover, banks in Lebanon aim to retain the employees and ensure their commitment to the organization due to the high costs of turnover, recruiting, and training new employees.

The objectives of this research study are listed in the below points:

1) Understand and explore the effect of the core dimensions of employee empowerment on organizational commitment.

2) Analyze the relationship between job autonomy, employee motivation, job enrichment and delegation with the organizational commitment.

3) Evaluate the results and give recommendation to increase the level of employees' commitment in the Lebanese banking sector.

\subsection{Hypotheses}

The hypotheses to be tested through research for this study are defined as follows:

H1: The components of employee empowerment reflect a positive relationship with the organizational commitment. 


\section{Macrothink}

International Journal of Human Resource Studies

ISSN 2162-3058

2018, Vol. 8, No. 3

H1.1: Job autonomy is positively related with the organizational commitment in the Lebanese banking sector.

H1.2: Employee motivation is positively related with the organizational commitment in the Lebanese banking sector.

H1.3: Training is positively related with the organizational commitment in the Lebanese banking sector.

H1.4: Compensation is positively related with the organizational commitment in the Lebanese banking sector.

\section{Literature Review}

\subsection{Employee Empowerment and Organizational Commitment}

Scholars have conducted several studies regarding the organizational commitment which showed that organizational commitment has significant implications on both employees and organizations. As stated by Mowday in 1982, organizational commitment represents the relative strength of the individual's identification and participation in a certain company. With respect to Meyer and Allen (1997), a committed employee goes to his/her work frequently, is productive and effective during the entire working day, stays with the organization through ups and downs, cares for the organization's assets, and ultimately shares the goals and values of the organization. Thus, organizational commitment affects both job performance and turnover (O'Reilly \& Chatman, 1986). Moreover, given that it affects job movement, community stability, and national productivity, it is also argued that organizational commitment affects all stakeholders (Porter et al., 1974).

According to Hancer and George (2003), the origin of empowerment can be traced to the theory developed by Douglas McGregor that began in the field of organizational behavior. McGregor developed a theory called "Theory Y," based on the concept that employees' participation, productivity, and motivation can be achieved and improved by designing more flexible and autonomous occupations. Demirci \& Erbas (2010) explained empowerment as the combination of four components: power, information, knowledge, and rewards (Table 1). Petter et al. (2002) clarified seven different dimensions of employee empowerment which are power, information, knowledge and skills, decision making, autonomy, responsibility, and initiative and creativity.

Table 1. Instruments of Empowerment

\begin{tabular}{c|c|c|c}
\hline \multicolumn{4}{c}{ Empowerment $=$} \\
Power $\times$ Information $\times$ Knowledge $\times$ Rewards \\
\hline Power & Information & Knowledge & Rewards \\
\hline Autonomy & Feedback & Training & Compensation \\
\hline Authority & Role Clarification & Counseling & Career Planning \\
\hline Delegation & Motivation & Appraisal & Job Enrichment \\
\hline
\end{tabular}

Source: Demirci \& Erbas, 2010

A number of studies were conducted to test the relationship between employee empowerment 
and organizational commitment. In 2002, Heather K. Spence Laschinger and Judith Shamian conducted a study under the title of "The impact of workplace empowerment, organizational trust on staff nurses' work satisfaction and organizational commitment". This study was done on a random sample of 412 Canadian staff nurses which concluded that empowered employees experienced greater commitment towards their organizations. In 2004, another study was done by Onne Janssen on a sample of 91 secondary school teachers in the Netherlands titled "The barrier effect of conflict with superiors in the relationship between employee empowerment and organizational commitment." The conducted Pearson correlations and multiple regression analyses confirmed that teachers with higher authority rankings are expected to be more committed than those with lower authority.

\subsection{Job Autonomy and Organizational Commitment}

Job autonomy is considered as a core characteristic of work and has been widely studied by a number of scholars (Smith, Fisher, \& Sale, 2001). In 1995, Karasek related job autonomy to customers' potentials of making decisions regarding their jobs. It is conceptualized as the degree of power that employees have to delegate their own tasks.

Researchers have done studies to find the relationship between job autonomy and organizational commitment. In 2012, David Joseph Dude in his thesis "Organizational commitment of principals: The effects of job autonomy, empowerment, and distributive justice", done in the Midwest United States, supports the hypothesis that higher levels of job autonomy will be associated with higher levels of organizational commitment. This study was done on K-12 elementary and secondary principals from public, private/parochial schools, and charter schools. Another study was done by Mirsim Gashi in 2014 under the title of "The influence of work overload and autonomy on job satisfaction, organizational commitment, and turnover intent: the case of Kosovo" showed that there exists full mediation of job satisfaction between autonomy and organizational commitment. This study was done on 150 respondents from different industry sectors of Kosovo.

\subsection{Employee Motivation and Organizational Commitment}

Motivation is a widely studied field that has origins in many academic disciplines including education, sociology, psychology, economics, and political science. According to Jones et al (2010), motivation is the psychological forces which trace the direction of a person's level of effort and his/her persistence facing obstacles.

In 2006, Sébastien Castaing conducted a study on 754 civil servants in France under the title of "The Effects of Psychological Contract Fulfilment and Public Service Motivation on Organizational Commitment in the French Civil Service". The results showed that public service motivation explains organizational commitment in French public administration. In 2013, the empirical study "Relationship between Employee Motivation, Satisfaction and Organizational Commitment" done in India by S. ArunKumar showed that there is a positive correlation between overall motivation and organizational commitment. The sample was extracted from the staff establishment of an X Retailer Headquarters in Malaysia and consisted of 118 employees across the top and middle management, as well as general staff 
levels. Another dissertation "How intrinsic motivation and extrinsic motivation affect organizational commitment and job satisfaction" done by 2014 by Yungong Huang showed that motivation is positively associated with organizational commitment. This study consists of 330 anonymous responses collected through an online survey system based on Google Docs and divided between 136 responses from the US and 194 responses from China. In 2000, Moon Jae conducted a study "Organizational Commitment Revisited in New Public Management: Motivation, Organizational Culture, Sector, and Managerial Level” in which data were collected from public organizations in the Syracuse and Albany, New York areas. The results showed that motivation is significantly associated with organizational commitment in the public sector.

\subsection{Training and Organizational Commitment}

Training is considered one of the major areas of the Human Resource Management that leads to effective usage of the human resources. For this reason, most companies nowadays insist on the importance of training as a key influence on success.

In 2007, Mohammed Asad Shareef Al-Emadi and Michael J. Marqua conducted a research "Relationship between employees' beliefs regarding training benefits and employees' organizational commitment in a petroleum company in the State of Qatar". It was done on a total of 283 responses and resulted in a positive relationship between employees training and organizational commitment. In 2010, Cagri Bulut and Osman Culha found out in their study "The effects of organizational training on organizational commitment" that organizational commitment is positively affected by the organizational training. 298 questionnaires were considered for this study collected from four- and five-star hotels located in Izmir, the largest city of the Aegean in Turkey. In December 2013, the dissertation of Eun-Chung Chung "The Relationship of Training and Organizational Commitment in One Korean Organization" showed that there is a positive correlation between different aspects of training and organizational commitment. For this study, participants consisted of 269 employees from one large firm in Korea.

\subsection{Compensation and Organizational Commitment}

Compensation is the systematic approach of offering monetary value for individuals in exchange for work they had performed. It is the benefit that the individual receives in the form of pay, wages and rewards for the purpose of increasing his/her performance (Brown, 2003).

In 2006, Andreas Dockel, Johan Basson and Melinde Coetzee conducted the research "The effect of retention factors on organizational commitment: an investigation of high technology employees". It was done on a sample of 94 professional technicians from South African owned telecommunications companies. The results revealed that compensation, job characteristics, and supervisor support appeared to have a statistically significant influence on the development of organizational commitment. Another study "The interactive effect of collectivism and organizational rewards on affective organizational commitment" was done on a racially diverse set of young professionals in the USA. It was conducted by Ian $\mathrm{O}$. Williamson, Meredith F. Burnett, and Kathryn M. Bartol in 2009 and the findings suggest that 


\section{Macrothink}

International Journal of Human Resource Studies

ISSN 2162-3058 2018, Vol. 8, No. 3

organizations can boost the existing employees' commitment according to the rewards provided to them. In 2016, Ogunnaike, O. O et al concluded in their project "Empirical Appraisal of Compensation and Organizational Commitment in Education Management" that adequate compensation enhances employee commitment. Their study included 172 teachers from selected secondary schools in Nigeria. Moreover, in 2015, M. Gathungu, Mike A. Iravo, G.S. Namusonge have conducted a study in Kenya "Effect of Promotion Strategies on the Organizational Commitment of Banking Sector Employees in Kenya" which resulted that promotion and commitment do not have a strong relationship. The target population in this study included forty-three commercial banks in Kenya which accounted for 311 respondents.

\section{Research Methodology}

\subsection{Theoretical Framework}

Based on the literature review, this research has developed a conceptual framework which shows the scope of the study and helped authors to test the proposed hypotheses.

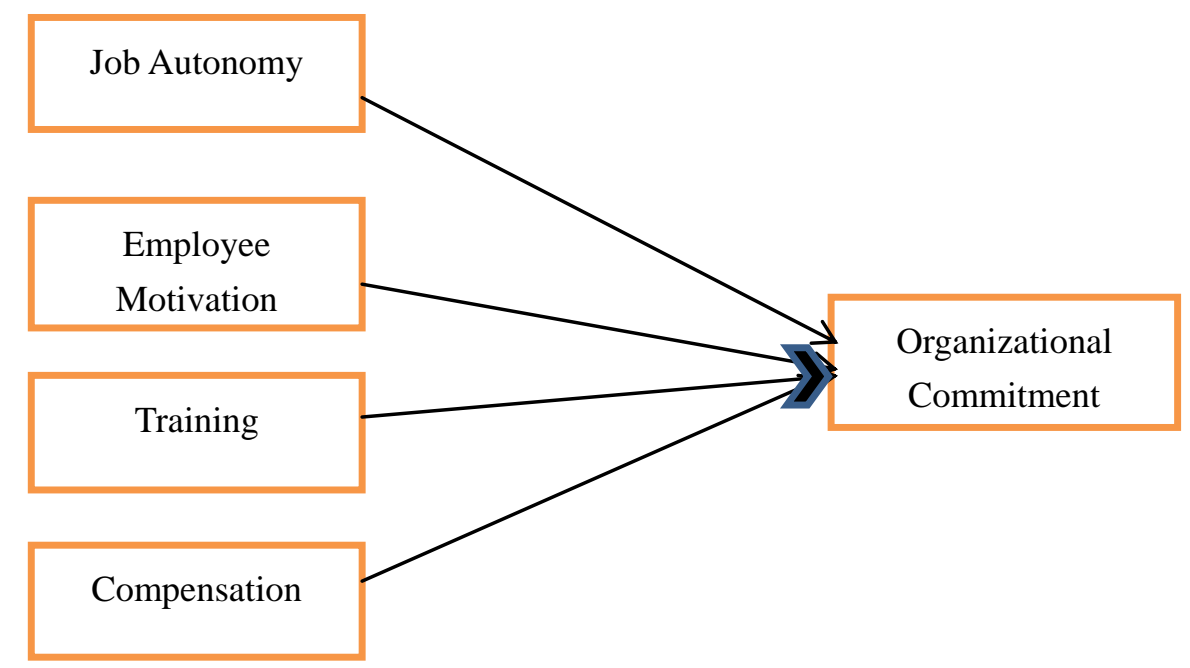

Figure 1.Theoratical framework

\subsection{Data Collection and Analysis}

The study was conducted at very well-known retail banks in Lebanon which are considered among the alpha banks whose deposits exceed \$2B. The Alpha Group's total assets sustained their healthy growth in the first quarter of 2016. According to Bank Data, the Alpha Group's total assets rose by $4.9 \%$ year-on-year to $\$ 203.49$ B. As such, the assets of the Alpha Group would represent more than $400 \%$ of Lebanon's GDP. The selected banks are Blom bank, Audi bank, Bank Med, Byblos Bank, Bank of Beirut, Lebanon and Gulf Bank, Mawarid bank, BBAC bank, and Banque Libano-Française.

A sample of 200 random employees from different departments in banks was chosen as the target population of the study. An overall of 123 questionnaires were filled and returned by the employees, which means that the response rate was around 62\%. 65 didn't reply and 12 
were considered as errors. These banks were chosen based on the researcher's accessibility to its employees and their willingness to participate in the study.

Consequently, upon the approval of the human resource departments or the approval of the branch manager from the selected banks, the researcher was able to distribute the questionnaires. Each bank has taken its required time so that the employees can answer the surveys and the researcher in his/her turn had kept in contact with the manager by phone or by email. Finally, when the employees filled up the questionnaires, it was either collected back by hand or sent by the bank via email.

Finally, the Statistical Package for the Social Sciences (SPSS), version 21, was used in this project to conduct the statistical analysis, data management, and data documentation. The researcher had computed both descriptive and inferential statistics.

\section{Results and Discussion}

\subsection{Sample Profile}

From the below table 2, the statistics display that 52.8 percent of the respondents are male and 47.2 percent are female which reflects that the banking sector in Lebanon shares a similar percentage for the gender of the workforce. This is because Lebanon represents a link between the East and West and has adopted the Western mentality in the workforce gender equality. This has caused a reduction in discrimination between male and female in the workforce. Moreover, the Lebanese Labor Law does not differentiate between genders neither in labor rights nor in remuneration. The well-structured establishment for organizing labor power has also supported women in Lebanon to perform different workplace tasks and to hold the same responsibilities as men in various sectors. This greatly reflects the culture and openness of the mentality of the Lebanese people

Table 2. Gender of the respondents

\begin{tabular}{l|l|l}
\hline \multicolumn{1}{c|}{ Gender variables } & Frequency & Percentage \\
\hline Female & 58 & 47.2 \\
Male & 65 & 52.8 \\
Total & $\mathbf{1 2 3}$ & $\mathbf{1 0 0}$ \\
\hline
\end{tabular}

Table 3. Age of the respondents

\begin{tabular}{c|c|c}
\hline Age Variables & Frequency & Percentage \\
\hline $21-29$ & 51 & 41.5 \\
$30-39$ & 37 & 30.1 \\
$40-49$ & 14 & 11.4 \\
Above 49 & 21 & 17.1 \\
Total & $\mathbf{1 2 3}$ & $\mathbf{1 0 0}$ \\
\hline
\end{tabular}

Table 3 indicated that among the respondents, 17.1 percent are between 50 and 64; 11.4 percent are between 40 and 49; 30.1 percent are between 30 and 39 years, and 41.5 percent are between 21 and 29 years. The high percentage of the age between 21 and 29 years is 
predominant because banks prefer fresh youth graduate as they are the blood of the bank and technology is part of their DNA. In addition, fresh graduates require lower salaries and give innovative ideas and new perspectives. They are the masters of continuous learning and have ample technical and business skills. In addition, they have a great commitment towards work.

Table 4. Educational qualifications of the respondents

\begin{tabular}{c|c|c}
\hline Educational level variables & Frequency & Percentage \\
\hline Bachelor's degree holders & 76 & 61.8 \\
Master's degree holders & 44 & 35.8 \\
PhD degree holders & 3 & 2.4 \\
Total & $\mathbf{1 2 3}$ & $\mathbf{1 0 0}$ \\
\hline
\end{tabular}

Table 4 showed that $61.8 \%$ of the respondents in the banking sector hold a Bachelor's degree and $35.8 \%$ of them hold a Master's degree. The cause behind the dominance of Bachelor holders is that Lebanon has taken significant measures to improve education in the recent years. Therefore, the Lebanese people are seeking higher education to be much more cultured. However, holding a master degree in the banking sector goes for several reasons. One of the reasons is helping the employees towards future improvement in the bank. In addition, it is considered as an added value to them.

Table 5. Salary of the respondents

\begin{tabular}{c|c|c}
\hline Salary per Month (in USD) & Frequency & Percentage \\
\hline $800 \rightarrow 1000$ & 34 & 27.6 \\
$1100 \rightarrow 2000$ & 55 & 44.7 \\
$2100 \rightarrow 3000$ & 17 & 13.8 \\
Above 3000 & 17 & 13.8 \\
Total & $\mathbf{1 2 3}$ & $\mathbf{1 0 0}$ \\
\hline
\end{tabular}

Table 5 provided information about salary in Lebanon is usually unreliable. However, published information indicates that in the most booming sectors 27.6percent of the respondents earn from $\$ 800$ to $\$ 1000$ per month; 44.7 percent earn from $\$ 1100$ to $\$ 2000$ per month; 13.8 percent respondents earn from $\$ 2100$ to $\$ 3000$ per month; and the remaining 13.8 percent earn more than $\$ 3000$ per month. This indicates a very good earning for a country where living is really expensive. It is also considered as a good level of salary when compared to the GDP in Lebanon. Hence, this reflects that the employees in the Lebanese banking sector are being well paid.

Table 6. Result of regression analysis through SPSS

\begin{tabular}{c|c|c|c}
\hline \multirow{2}{*}{ Variables } & \multicolumn{3}{|c}{ Coefficient } \\
\cline { 2 - 4 } & Beta & R squared & P-value \\
\hline Job Autonomy & .211 & .0445 & .019 \\
\hline Employee Motivation & .336 & .113 & .000 \\
\hline Training & .225 & .051 & .012 \\
\hline Compensation & .486 & .236 & .000 \\
\hline
\end{tabular}


The above table 6 has revealed the results of the multiple linear regression analysis exploring the relationship between job autonomy, motivation, training, compensation, and organizational commitment among employees in the Lebanese banking sector.

The testing of hypotheses using the linear regression presented the below relationships:

1) Job autonomy and organizational commitment; it showed through analysis that job autonomy has a positive relationship with organizational commitment and thus supported the hypothesis.

2) Motivation and organizational commitment; it showed through analysis that motivation has a positive relationship with organizational commitment and thus supported the hypothesis.

3) Training and organizational commitment; it showed through analysis that training has a positive relationship with organizational commitment and thus supported the hypothesis.

4) Compensation and organizational commitment; it showed through analysis that compensation has a positive relation with organizational commitment and thus supported the hypothesis.

The aforementioned findings validated the proposed hypotheses and indicated that there is a positive relationship between the four main components of employee empowerment and organizational commitment. Consequently, hypothesis one which proposed a positive relationship between employee empowerment as an independent variable and organizational commitment as a dependent variable has also been supported.

However, the next chapter will discuss the findings obtained based on the previous literature covering the subjects of job autonomy, motivation, training, compensation, and organizational commitment.

\subsection{Job Autonomy and Organizational Commitment}

Upon the dynamic change in the Lebanese workforce demography as women started handling different job positions, more couples are obliged to hold both work and family responsibilities. Job autonomy allows employees to work during times suited to their personal needs and give them more freedom to schedule their work. In 2010, Dinger stated that highly autonomous employees can organize their work efficiently which potentially reduces the problems in integrating their work and family demands. These employees expect that their organizations would take their situation into consideration and help them to integrate work and family demands. Thus, the employee who perceives that their expectations have been met would feel more committed to staying in the organization.

\subsection{Motivation and Organizational Commitment}

Lebanese banks were among the first sectors in Lebanon that invested in the human resources because of its importance as a main asset and source of competitive advantage. In order to make employees satisfied and committed to their jobs, there is a need for strong and effective motivation. The banks in Lebanon exert significant effort to motivate their employees so that their performance gets boosted. Motivation makes the individuals satisfied as they regard 
themselves as a crucial factor that has a main role in the company. When this attention is greatly given to the employees, consequently, they will strive to fulfil the objectives of the organization and pursue high retention. When employees are motivated they feel enthusiastic at work and start aligning with the organizational goals and objectives.

\subsection{Training and Organizational Commitment}

Enhancing the employees' training program will enrich employees with thriving for retention. By investing the appropriate training in employees, they will develop a greater sense of self-worth as they become more valuable to the company. Moreover, trained employees are more likely to take pride in the organizational achievements, believe in its goals, and become committed to their work. Therefore, they will exhibit higher levels of performance in their jobs. Since training has a positive effect on productivity, employee training is worth the investment (Jennifer et. al 2013).

\subsection{Compensation and Organizational Commitment}

Compensation is considered as the main factor to improve the employee's work and productivity. Upon that, the organizations should consider the compensation in promoting commitment among employees. Furthermore, the significance of having good salaries for the employees in banks is to fulfill their own needs such as physiological safety need-based in the Maslow's theory. In 1964, Maslow's stated that the need for people starts from the basic need reaching the high level of need. These needs are available in every human being; therefore, any failure to satisfy a basic need will prevent the next need in the hierarchy to be achieved. According to the results of the study, the majority of the employees in the Lebanese banking sector are getting paid between $\$ 1100$ and $\$ 2000$ per month. This salary is considered relatively good compared to the GDP of the country. Because of the Lebanese hard financial situations and the expensiveness of living in this country, compensation and especially the financial rewards have become a crucial part of the Lebanese daily life. Thus, the employees' life has become highly dependent on the financial standards in this hard economic situation. So having a stable job, in which it offers a good salary accompanied with better benefits, has become essential for every single employee to attain. Overall, improving compensation will improve and ensure the meeting of the organizational goals and objectives.

\section{Conclusion and Recommendations}

Valuable data was recognized in this research that studied the relationship between employee empowerment with the organizational commitment. Thus, the purpose of this study was successfully accomplished. However, several areas are still vague and must be investigated by future research.

First, the same research can be done in the future by gathering data from more than one Lebanese sector not only the banking sector. By this, the researches will be able to compare different sectors that are studying the same project subject and give adequate recommendations for each. Second, this research examines the effect of employee empowerment on the organizational commitment as whole. Hence, future studies may 
examine the relationship between the same independent variables of this study with the three components of the organizational commitment affective, normative, and continuous commitment. Furthermore, this study has focused on four components of the organizational commitment only which are job autonomy, motivation, training, and compensation. Authority, role clarification, counseling, career planning, delegation, feedback, appraisal, and job enrichment are all components of employee empowerment as mentioned before in the literature review. Thus, future research can tackle more components of the independent variable that was studied in this research. In addition, many variables that are directly related to the socio-cultural behavior of the Lebanese individuals can be taken into consideration for future studies. Accordingly, these variables will be studied to examine their relationship with the organizational commitment. This will help managers to establish different variables that enhance the commitment of employees which will consequently lead to more growth of the companies.

\section{References}

Achi, G., \& Ayache, G. (2001). L'histoire de la banque au Liban. Retrieved from http://www.worldcat.org/title/histoire-de-la-banque-auliban/oclc/725480522.

ArunKumar, S. (2013). Relationship between Employee Motivation, Satisfaction and Organizational Commitment. International Journal of Management and Business Research, 4(2), 81-93.

Brown, D. (2003). Reward Strategies. Journal of Personnel Management, 17(1), 20-41.

Bulut, C., \& Culha, O. (2010). The effects of organizational training on organizational commitment. International Journal of Training and Development, 14(4), 309- 322. https://doi.org/10.1111/j.1468-2419.2010.00360.x

Castaing, S. (2006). The Effects of Psychological Contract Fulfilment and Public Service Motivation on Organizational Commitment in the French Civil Service. Public Policy and Administration, 21(1), 84-98. https://doi.org/10.1177/095207670602100106

Chung, E. (2013, December). The relationship of training and organizational commitment in One Korean organization. Retrieved from http://hdl.handle.net/11299/162440.

Demirci, K., \& Erbas, A. (2010, June). Employee empowerment and its effect on organizational performance. Retrieved from https://pdfs.semanticscholar.org/06c0/169f6da43fe9fb275bbb3f13d49e53598b5c.pdf

Dinger, M. (2010). A study of work-family conflict among IT professionals: Job characteristics, individual values and management practices. Journal of Organizational Computing and Electronic Commerce, 20(1), 91-121. https://doi.org/10.1080/10919390903482341

Döckel, A., Basson, J., \& Coetzee, M. (2006). The effect of retention factors on organizational commitment: An investigation of high technology employees. SA Journal of Human Resource Management, 4(2), 20-28. https://doi.org/10.4102/sajhrm.v4i2.91

Dude, D. J. (2012). Organizational commitment of principals: The effects of job autonomy, 
empowerment, and distributive justice. Retrieved from http://ir.uiowa.edu/etd/2863.

Emadi, M., \& Marquardt, M. (2007). Relationship between employees' beliefs regarding training benefits and employees' organizational commitment in a petroleum company in the State of Qatar. International Journal of Training and Development, 11(1), 49-70. https://doi.org/10.1111/j.1468-2419.2007.00269.x

Emerson, A. (2012). The Benefits of Employee Empowerment. Credit Union Times

Gashi, M. (2014). The influence of work overload and autonomy on job satisfaction, organizational commitment and turnover intent: the case of Kosovo: Master Thesis Human Resource Studies. Tilburg University.

Gathungu, E., \& Namusonge, S. (2015). Effect of Promotion Strategies on the Organizational Commitment of Banking Sector Employees in Kenya. IOSR Journal of Humanities and Social Science, 20(10), 36-45.

Hancer, M., \& George, T. (2003). Psychological empowerment of non-supervisory employees working in full-service restaurants. International Journal of Hospitality Management, 22(1), 3-16. https://doi.org/10.1016/S0278-4319(02)00032-4

Huang, Y. (2014). How intrinsic motivation and extrinsic motivation affect organizational commitment and job satisfaction (Doctoral Dissertation). Retrieved from https://repositories.tdl.org/tamiu-ir/bitstream/handle/2152.4/71/HUANG-DISSERTATI ON-2014.pdf?sequence $=1$

Ian, O. W., Meredith, F. B., \& Kathryn, M. B. (2009) .The interactive effect of collectivism and organizational rewards on affective organizational commitment, Cross Cultural Management: An International Journal, 16(1), 28-43.

Janssen, O. (2004). The barrier effect of conflict with superiors in the relationship between employee empowerment and organizational commitment. Work \& Stress, 18(1), 56-65. https://doi.org/10.1080/02678370410001690466

Jennifer, C. P., Brian, P. C., \& Steven, D. F. (2013). Return on investment for workplace training: the Canadian experience International. Journal of Training and Development, 17(1).

Jones, R., Jennifer, G., \& Hill, C. (2010). Contemporary Management. USA: McGraw-Hill.

Karasek, R, A. (1995). Job content instrument: Questionnaire and user's guide. Journal of Occupational Health Psychology, 3(4), 322-355. https://doi.org/10.1037/1076-8998.3.4.322

Laschinger, H., Finegan, J., \& Shamian, J. (2002). The impact of workplace empowerment, organizational trust on staff nurses' work satisfaction and organizational commitment. Health Care Manage Review, 26(3), 7-23. https://doi.org/10.1097/00004010-200107000-00002

Maslow, A. H. (1943). A theory of human motivation. Psychological Review, 50(4), 370. https://doi.org/10.1037/h0054346

Meyer, J., \& Allen, N. (1997). Commitment in the Workplace: Theory, Research, and 
Application, London: Sage Publications.

Moon, J. (2000). Organizational Commitment Revisited in New Public Management: Motivation, Organizational, Culture, Sector, and Managerial Level. Public Performance \& Management Review, 24(2), 177-194. https://doi.org/10.2307/3381267

Mowday, R. T., Porter, I. W., \& Steers, R. M. (1982). Employee-Organization Linkages. The Psychology of Commitment, Absenteeism, Turnover. New York: Academic Press

O’Reilly, C. A., \& Chatman, J. A. (1986). Organizational commitment and psychological attachment: The effects of compliance, identification and internalization on prosocial behavior. Journal of Applied psychology, 71(2), 492-499. https://doi.org/10.1037/0021-9010.71.3.492

Ogunnaike, O., Oyewunmi, A., \& Famuwagun, E. (2016). Empirical Appraisal of Compensation and Organizational Commitment in Education Management. Mediterranean Journal of Social Sciences, 7(3), 296-300. https://doi.org/10.5901/mjss.2016.v7n3p296

Petter, J., Byrnes, P., Choi, D., Fegan, F., \& Miller, R. (2002), Dimensions and patterns in employee empowerment: assessing what matters to street-level bureaucrats. Journal of Public Administration Research and Theory, 12(3), 377-400. https://doi.org/10.1093/oxfordjournals.jpart.a003539

Porter, L. W., Steers, R. M., Mowday, R. T., \& Boulian, P. V. (1974). Organizational commitment. Job satisfaction, and turnover among psychiatric technicians. Journal of Applied Psychology, 59(2), 603-609. https://doi.org/10.1037/h0037335

Reichers, A. E. (1985). A review and reconceptualization of organizational commitment, Academy of Management Review, 10(1), 465-476. https://doi.org/10.5465/amr.1985.4278960

Smith, B., Fischer, R., \& Sale, N. (2001). Cross-cultural industrial/organizational psychology. International Review of Industrial and Organizational Psychology, 16(1), 147-194.

\section{Appendices}

Survey

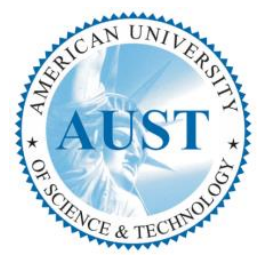

This survey consists of six parts. In the first part, you will be asked to provide general information about you and your department. In the following parts, number of statements will be presented to you, where you will be asked to indicate how those statements are similar to your opinion.

Section A

For each question, please check the item that applies to your case: 
Demographics Information:

1. Gender: $\quad$ Male $\square \quad$ Female

2. Age: $21-29 \square$

\section{Age: $21-29$ \\ 3. Marital Status: Single}

$$
30-39
$$

$40-49$

above 49

Married

Divorced

Widowed

4. Education Level: Bachelor Degree

Masters

$\mathrm{PhD}$

5. Salary/Month:

$$
\$ 800-\$ 1000
$$

$\$ 1100-\$ 2000$

$\$ 2100-\$ 3000$

$>\$ 3000$

Please indicate the extent to which you agree or disagree with the following statements by marking the appropriate boxes. Use the scales below for sections B, C, D, E, \& F:

$\begin{array}{lllll}1 & 2 & 3 & 4 & 5\end{array}$

Strongly Disagree

Disagree

Neutral

Agree

Strongly Agree

$\underline{\text { Section B }}$

\begin{tabular}{|c|l|l|l|l|l|l|}
\hline 6. & Your position allows you to make independent decisions. & 1 & 2 & 3 & 4 & 5 \\
\hline 7. & You choose how to perform your work. & 1 & 2 & 3 & 4 & 5 \\
\hline 8. & Your job requires that you learn new things. & 1 & 2 & 3 & 4 & 5 \\
\hline 9. & You participate in the decisions for the company. & 1 & 2 & 3 & 4 & 5 \\
\hline
\end{tabular}

Section C

\begin{tabular}{|c|l|c|c|c|c|c|}
\hline 10. & $\begin{array}{l}\text { You are pleased with the career advancement opportunities } \\
\text { available to you. }\end{array}$ & 1 & 2 & 4 & 5 \\
\hline 11. & You are inspired to meet your goals at work. & 1 & 2 & 3 & 4 & 5 \\
\hline 12. & You are determined to give your best effort at work each day. & 1 & 2 & 3 & 4 & 5 \\
\hline 13. & $\begin{array}{l}\text { Employees in your organization take the initiative to help } \\
\text { other employees when the need arises. }\end{array}$ & 1 & 2 & 3 & 4 & 5 \\
\hline
\end{tabular}

Section D

\begin{tabular}{|c|l|c|c|c|c|c|}
\hline 14. & You receive the training you need to do your job well. & 1 & 2 & 3 & 4 & 5 \\
\hline 15. & $\begin{array}{l}\text { The training sessions conducted in your organization are } \\
\text { useful. }\end{array}$ & 1 & 2 & 3 & 4 & 5 \\
\hline 16. & You like to attend the training programs. & 1 & 2 & 3 & 4 & 5 \\
\hline 17. & $\begin{array}{l}\text { Your organization considers training as part of its business } \\
\text { strategy. }\end{array}$ & 1 & 2 & 3 & 4 & 5 \\
\hline
\end{tabular}

$\underline{\text { Section E }}$

\begin{tabular}{|c|l|c|c|c|c|c|}
\hline 14. & You are satisfied with the salary you receive. & 1 & 2 & 3 & 4 & 5 \\
\hline 15. & You are satisfied with your bonus you receive. & 1 & 2 & 3 & 4 & 5 \\
\hline
\end{tabular}




\begin{tabular}{|c|l|l|l|l|l|l|}
\hline 16. & Your salary matches the salary scale of the banking sector. & 1 & 2 & 3 & 4 & 5 \\
\hline 17. & Your salary increases based on your career advancement. & 1 & 2 & 3 & 4 & 5 \\
\hline
\end{tabular}

$\underline{\text { Section F }}$

\begin{tabular}{|c|l|c|c|c|c|c|}
\hline 18. & $\begin{array}{l}\text { You would be very happy to spend the rest of your career with } \\
\text { this organization. }\end{array}$ & 2 & 3 & 4 & 5 \\
\hline 19. & $\begin{array}{l}\text { You really feel as if this organization's problems are your } \\
\text { own. }\end{array}$ & 1 & 2 & 3 & 4 & 5 \\
\hline 20. & $\begin{array}{l}\text { You do not feel a strong sense of belonging to your } \\
\text { organization. }\end{array}$ & 2 & 3 & 4 & 5 \\
\hline 21. & $\begin{array}{l}\text { It would be very hard for you to leave your organization right } \\
\text { now, even if you wanted to. }\end{array}$ & 1 & 2 & 4 & 5 \\
\hline 22. & $\begin{array}{l}\text { You believe that a person must always be loyal to his or her } \\
\text { organization. }\end{array}$ & 1 & 2 & 3 & 4 & 5 \\
\hline 23. & $\begin{array}{l}\text { If I got another offer for a better job elsewhere I would feel it } \\
\text { was right to leave my organization. }\end{array}$ & 2 & 3 & 4 & 5 \\
\hline
\end{tabular}

\section{Copyright Disclaimer}

Copyright for this article is retained by the author(s), with first publication rights granted to the journal.

This is an open-access article distributed under the terms and conditions of the Creative Commons Attribution license (http://creativecommons.org/licenses/by/4.0/). 